\title{
Co-creating Innovative Learning Environments: LEaRN's Decade of Discovery
}

\author{
Kenn Fisher
}

\begin{abstract}
This forward provides an overview of earlier LEaRN work carried out leading up to this book. It also explores some of the pedagogy and spatial tropes which have emerged over past decades. Whilst there have been many explorative innovations over that time, very few have been scalable and sufficiently resilient to dislodge the primordial hold that the Industrial Age classroom has taken in school design for over a century. Many attempts have been made to align pedagogy and space, but the classical classroom learning container remains in large part due to teacher mindsets. The Transitions suggested in these chapters may well be a seminal moment in the history of school design as the ILETC project nears its final stages of discovery.
\end{abstract}

\section{Context}

The work that this book covers is the latest manuscript emerging from a succession of nested projects commencing in 2007 at The University of Melbourne. This series of connected projects carried out since 2007 were largely directed towards understanding and developing an evidence-base on the nature of the relationship between student learning and the design of learning environments. These studies included various Australian Research Council Grant-funded projects, a number of large research consultancies with education departments, and several University-funded seed grant projects.

The projects were all completed under the aegis of the cross-disciplinary Learning Environments Applied Research Network (LEaRN) which was founded in 2008 by the Melbourne School of Design; the Melbourne Graduate School of Education; and the Melbourne Medical School. Collaborating institutional industry partners included schools and ministries of education, with industry professional practice partners consisting of various companies from the school building procurement sector.

K. Fisher ( $\varangle)$

The University of Melbourne, Melbourne, VIC, Australia

e-mail: fisherk@unimelb.edu.au 
These research and consulting studies have sequentially tackled the emergence and the effectiveness of innovative learning environments with a view to seeking links to their impact on student learning outcomes. However, few of these studies focused significantly on the practice of teachers. Furthermore, much of the literature in the educational discourse does not consider the impact of the physical learning environment on teacher practice. Indeed, there is a significant silence in the role of space in educational environments and how space and place may be integral to the whole teaching and learning process (Dovey \& Fisher, 2014).

\section{Teaching and Learning Theories}

Nevertheless, there is a massive amount of peer-reviewed research on both teaching and learning and currently there are many models of both in practice in schools worldwide. Teaching and learning are both at the heart of school education, supported by the curriculum and various complementary systems as illustrated by Zierer (2015) (Fig. 1).

Zierer's (2015) use of the term didactic is, in German parlance, related to teaching being based on post-enlightenment evidence-based content and knowledge. Moving into the twenty-first century, where increasingly dialectic or Socratic models of teaching are being used to promote active learning practices, there needs to be significantly more focus addressed to the supporting structures in education, of which both the physical and virtual environments combined are a critical part.

Zierer's (2015) use of the term 'mind frames' (after Hattie, 2012) is important here as it highlights the connection between historic teaching practices-which are now habituated-and current attempts at a more progressive teaching practice. Indeed the word innovation is now ubiquitous in education, yet such an approach-i.e.

Fig. 1 Teacher 'expertise' domains (Zierer, 2015). Used with permission from Klaus Zierer and the publisher: Taylor \& Francis Ltd, http:// www.tandfonline.com)

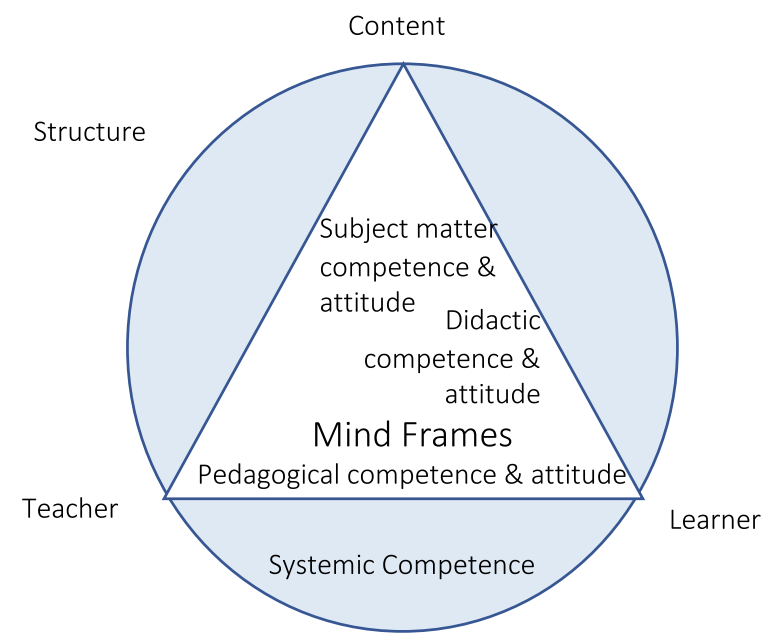


innovation-seems to evade the principle of scalability. These innovations whilst widespread remain isolated examples of what is possible. It has been said ${ }^{1}$ that 'the future is here it is just not widely distributed'.

This edited book on innovative learning environments and teacher change research builds on the succession of studies carried out through LEaRN, but is now turning the lens towards teacher practice and ways in which the 'habits of mind' of teachers can be transitioned in both the virtual and physical worlds to support an innovative teaching practice. In these prior studies by LEaRN it was found that the attributes of Hattie's (2012) eight Socratic led teacher mind frames suggest that teachers aspire to:

- Believe that their fundamental task is to evaluate the effect of their teaching on students' learning and achievement.

- Believe that the success of students is based on what teachers do (or don't do).

- Want to coach and model different ways of learning, rather than teaching.

- See assessment as feedback about their impact.

- Engage in dialogue, not monologue.

- Enjoy a challenge and never retreat to just 'doing their best'.

- Believe that it is their role to develop positive relationships in learning spaces and staffrooms.

- Inform parents about the nature of learning.

In drawing on both Hattie's (2012) and Dovey \& Fisher's (2014) work on the spatiality of these potential Socratic teaching approaches, it was proposed that teaching practices — or activities — could be summarised as follows, although clearly there are many more activities that are possible which are not itemised in this simplistic listing:

- Teacher facilitated presentation, direct instruction or large group discussion.

- Teacher facilitated small group discussion or instruction.

- Team teacher facilitated presentation, direct instruction or large group discussion.

- Collaborative/shared learning, supported by teachers as needed.

- One-on-one instruction.

- Individual learning.

These activities imply related learning spaces or affordances to support those pedagogical practices. What is now very well established in school operations is the use of data to inform teaching practice. Put another way, teaching practice should be evidence-based. But, as noted above, there is little extant evidence on how teachers use space in contemporary practice.

There is, however, a long history of attempting to link pedagogy and space going back over a millennium.

\footnotetext{
${ }^{1}$ Attributed to William Gibson in a radio interview in 1993.
} 


\section{A Brief Genealogy of the Evidence-Based Design of Learning Environments}

Early evidence first emerges when the then growing Islamic faith developed madrasa schools associated with mosques in the 8thC (Esposito, 2003). Some of these schools later evolved into the earliest universities e.g. the University of Al-Karaouine (859AD). A century or so later in the Western world cathedral schools emerged in association with monasteries. Some of these also transformed into universities including the Universities of Bologna (1088), Oxford (1096) and Cambridge (1209).

Abassi (2009) $)^{2}$ notes that it was at the earliest stages of the Industrial Revolution (with the invention of the steam engine in circa $1712^{3}$ ) that a more formal spatial approach to school education emerged in villages and cities with the acquisition and adaptation of various existing buildings. These soon morphed into the form of monitorial classrooms of the late 18thC, led by Drs Bell (1752-1832) and Lancaster (1776-1838). In the United States these were known as Lancastrian Schools ${ }^{4}$. These schools consisted of larger halls for 300 or so pupils seated in rows of desks with (student) monitors allocated to each section, together with space provided in the access ways at the sides for students to stand in semi-circles to observe lesson boards attached to the hall walls. These early arrangements were more focussed around student discipline management rather than student needs or teaching practice. Markus (1993, p92.) notes that:

In the monitorial schools the prescription for individual posture, gesture and eye contact were as detailed as those for groups of bodies controlled by painted lines or brass strips on the floor and monitors' rules. The face, and especially the eyes, signified character and willingness to learn. The sloping floor, the raised master's platform, the raked gallery and the tiered desks were direct instruments for visual surveillance.

In 1870 the United Kingdom Elementary Education Act introduced compulsory primary school education, whilst this also became the norm in the USA in $1918^{5}$ (this policy delay was most likely due to the State-based control of schooling in the USA). In this early UK building 'boom' the halls were subdivided into classrooms, where double desks were spaced so that teachers could move between them. Window sills were kept above eye level to minimise distractions.

Parallels existed in the United States, until Dewey (1916) sought to stimulate students through a more socially engaged form of learning related to lived experiences and the social construction of knowledge. This suggested more progressive building typologies such as Hillside Home School (Lloyd-Wright, 1902) ${ }^{6}$, which developed in parallel with a (global) health and hygiene approach in an attempt to combat disease epidemics at that time.

\footnotetext{
${ }^{2}$ A number of doctoral graduates from LEaRN have reviewed the historical development of school planning and design.

${ }^{3} \mathrm{http}: / /$ www.softschools.com/timelines/industrial_revolution_timeline/40/.

${ }^{4}$ https://www.raceforward.org/research/reports/historical-timeline-public-education-us.

5 https://people.howstuffworks.com/public-schools1.htm.

${ }^{6}$ https://www.flwright.org/researchexplore/wrightbuildings/hillsidehomeschool.
} 
After the First World War, as early modernism evolved, so did the concepts and theories of Freud and Jung, resulting in a suite of more radical school designs linked to the ideas of Montessori, Steiner and Isaacs, particularly in relation to early childhood development (Graham, 2008). Subsequent to the Second World War 'open air schools' emerged essentially modelled on modernist democratic principles although not really articulating a more democratic internal spatial arrangement. They were more about the outdoors. This was accompanied by the advent of 'bells and cells' or the 'eggcrate' spatial arrangements that proliferated at that time, many of which exist and persist to this day.

These post Second World War developments are covered by Abassi (2009) and also Darian-Smith \& Willis (2016) with the latter's book on 20thC school design and pedagogy. This book leads the evidence-based trajectory into the exemplary work of the Educational Facilities Laboratory (Marks, 2009) which was established in the United States in 1958, operating until 1986. This was more or less replaced a decade later in 1998 by the Educational Facilities Clearinghouse (EFL, 2019) a national US Government imitative attempt to provide some national 'guidelines' to the fifty or so State government school systems.

Mention is made by Abbasi and Darian-Smith \& Willis (2016) of many innovative examples which were not scaled but, apart from the massive expansion of modularised often precast 'cells and bells' schools in the 1960s to accommodate the emerging 'baby boomer' growth in student numbers, the most significant scaled innovative development was the 'open plan schools' movement of the 1970s. This (what turned out to be a flawed) experiment has had much written about the reasons for its failure (Logan, 2016).

The concept was originally conceived to reflect the democratised 'open' curriculum of that time-some readers will remember the civil unrest of the late 1960 s - in the design of the school i.e. a 'school without walls'. But the spatial innovation came without teacher professional development, no proper attention to acoustics in the open plan areas, and little access to the technologies that are becoming ubiquitous today, which are increasing the ability of students to work in personalised and self-directed ways.

Fast forward to Chap. 18 (Dussel, 2016) in Darian-Smith \& Willis (2016), and we now encounter the same open classroom problematic- how to make schooling authentic and connected to the outside world in a physical sense, whereas in a virtual sense connection is immutable?

This digital and Socratic (re-)evolution was specifically targeted by Australia's Victorian Department of Education when the Blueprint for Government Schools was developed in 2003 (Pike, 2005). Since then the Department has invested some AUS\$4 to 5 billion in new school designs, many-if not all—being innovative and bespoke to their local community following the previous Premier Jeff Kennett's launching of self-governing schools, whilst also cutting 7,000 school jobs and closing 350 schools (Knight, 1998). To this day all Victorian Schools have a self-Governing Council which has the power to select their architects. 
Such a Blueprint for space change warranted a deep consideration and reevaluation of the 1970s open school movement. The Victorian Department of Education initiated a study (Fisher, 2005) which aimed at 'linking pedagogy to space'. This approach received some international attention and was adapted for use in the United Kingdom's GBP55 Billion 'Building Schools for the Future' capital works programme in 2007 (BSF, 2019).

Subsequently, the establishment of LEaRN heralded a highly successful succession of research projects including Federal, State and Independent Sector grant funding totalling some $\$ 5$ million over the first decade (LEaRN, 2019).

This edited book, and the ILETC project—along with the additional LEaRN studies-has built upon the earlier work developed for the Victorian Education Department.

\section{Linking Pedagogy to Space}

It was decided by the ILETC team to use the spatial typologies of Dovey \& Fisher (2014) as a key framework to survey 800 schools across Australia and New Zealand to ascertain the extent to which each school advised that they were using innovative teaching and learning practices, and to what extent they were applying these approaches in matching innovative learning spaces. These spaces ranged from traditional classrooms (Type A, Fig. 2.) through a mix of classrooms and breakout spaces (Type B) to combined environments illustrated in Type E. The classroom layouts and the resulting data from the 800 schools are illustrated in Figs. 2, 3 and 4. The ILETC study then went on to explore the relationship between perceived 'deep learning' of students' and the teacher mind frame extent of adaptivity as shown in Fig. 3.

Finally, the relationship between teacher practices, deep learning and the spatial typology were examined as illustrated in Fig. 4.

The editors of this book - both Chief Investigators on this ILETC project-thus were able to build on the progression of the LEaRN body of work from its founding.

This led to two successive parallel ILETC international Transitions conferences (held in the USA and Europe) to gain a greater global understanding of the emerging evidence of these relationships. The transitions conferences were attended by $80-100$ participants on each continent with the invited peer-reviewed conference presentations transformed into book chapters. These were in turn peer-reviewed to finalise the shortlist of chapter authors herein.

Having gained an international oversight of teacher mind frames, deep learning, teacher practice and spatial typologies it was then necessary to refocus the lens to a more granular level in examining the integral components of teaching and learning educational systems.

The 16 selected final chapters were clustered into four themes, namely (1) Change $\&$ Risk-Creating a space: users and design; Agency and teacher collaboration in ILE; Achieving 'buzz'; Mitigating risk \& improved impact of ILE; Pedarchitecture; Interaction design research triangle for reading spaces; (2) Habitation-Mobility 
A

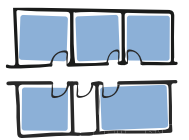

B

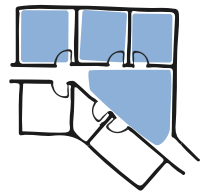

C

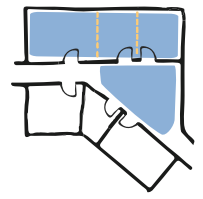

D

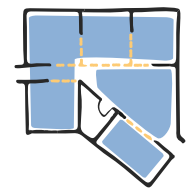

E

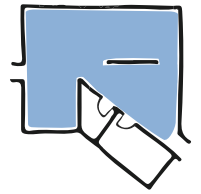

Type E : $14 \%$

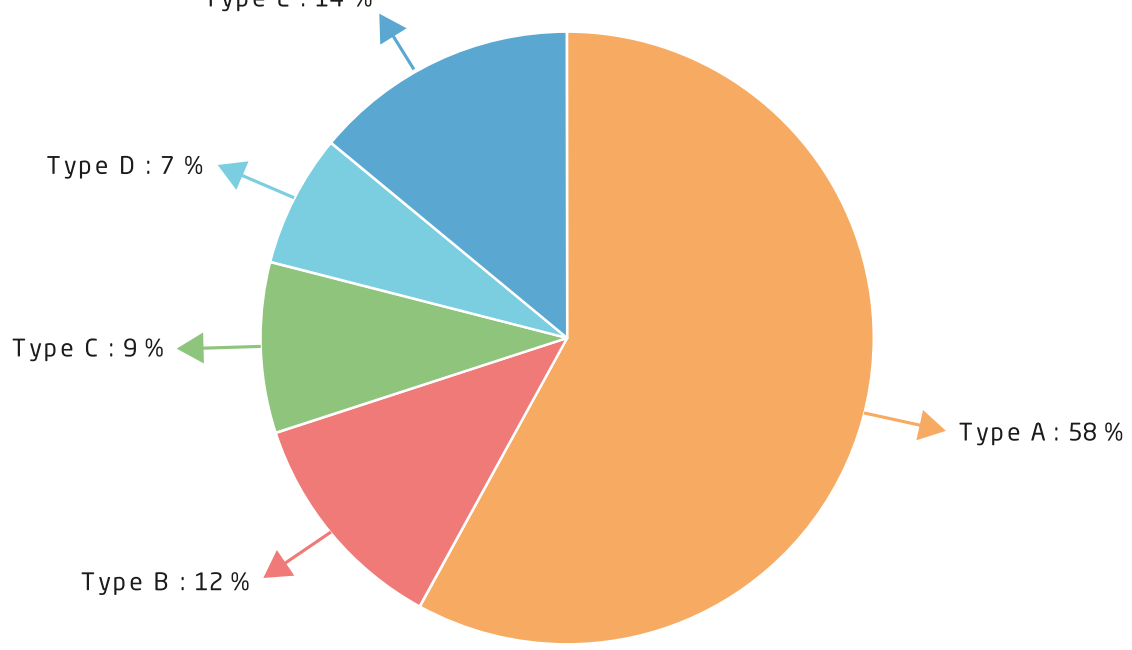

Fig. 2 Classroom typologies and School preferences in which to teach in an ILE format (Source: Imms, Mahat, Byers, and Murphy (2017). Reprinted with permission from the ILETC Project)

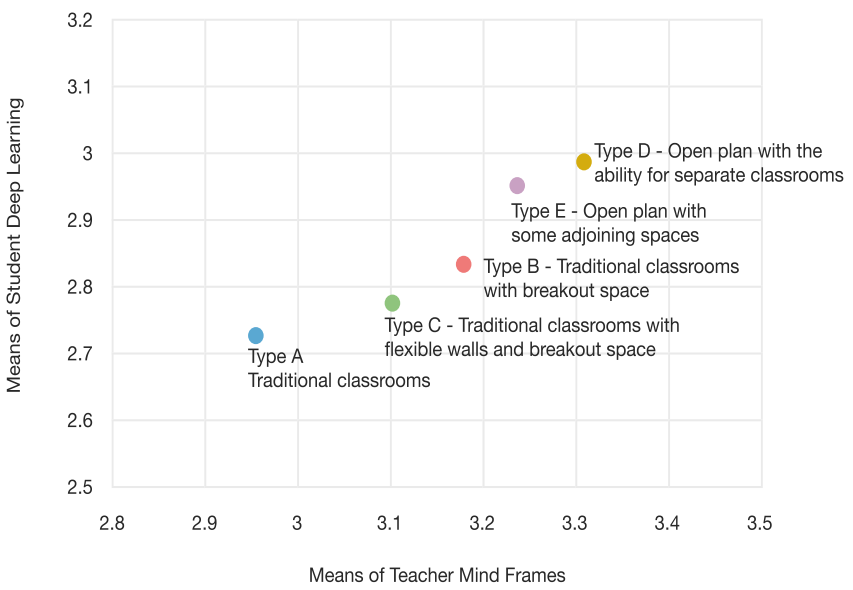

Fig. 3 Relationship between 'deep learning', teacher mind frame and spatial typology (Source: Imms et al. (2017). Reprinted with permission from the ILETC Project) 


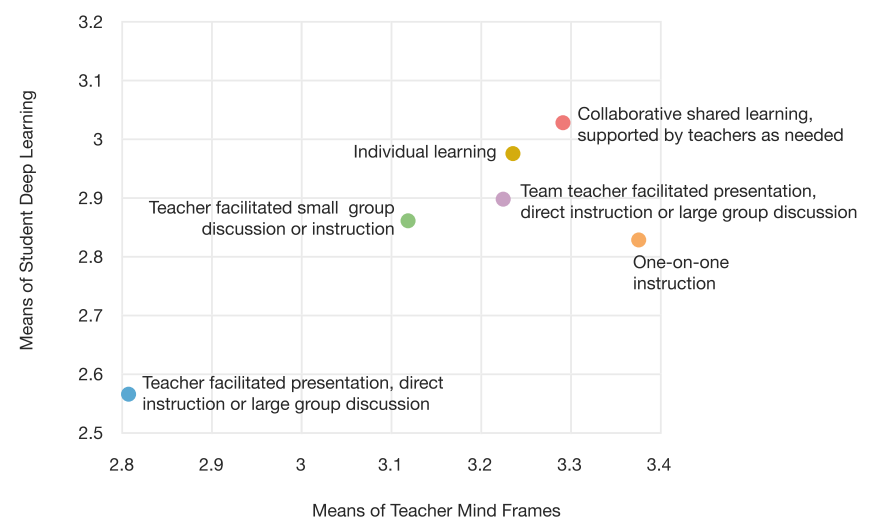

Fig. 4 Means of teacher mind frames and student deep learning categorised by most prevalent teaching approaches (Source: Imms (2017). Reprinted with permission from the ILETC Project)

of people for collaboration; Gadfly Collaborative data; Inclusive ILE's re acoustics; Interaction Geography; (3) Measurement-What does teaching and learning look like in ILE's; Lighting; Learning spaces and student learning; and Flaring and focusing.

The last section is a culmination of the research into praxis i.e. (4) Teacher Practice-The spirit of 'we'; ILE and socio-spatial entanglements for practice; and the 'Hack the school' toolkit.

What is very evident in the concept of Transitions is the wholistic nature of the variety of activities and enterprises into what is arguably a Transitions Ecosystem (Fig. 5).

Fig. 5 Key interactions within the ILETC Transitions Ecosystem for teacher practice

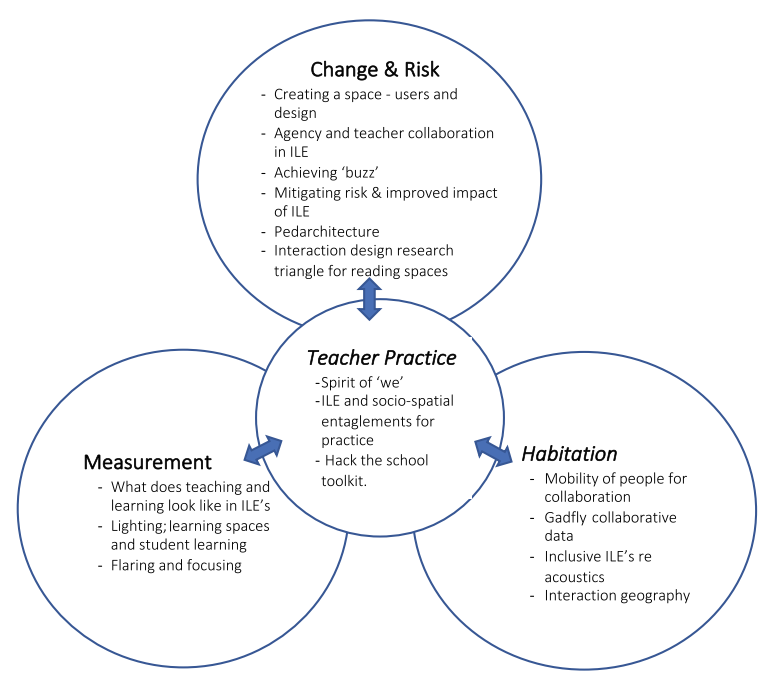




\section{The ILETC Transitions Ecosystem}

Figure 5 illustrates how all of the elements in a Transitions Ecosystem interact with each other as articulated by the Editors in the structure of this book. Each element must be considered synchronously with each other for the ILE outcome to be triangulated and resilient. The four key categories are considered by the Editors in a particular order and are discussed in this order by the editors as preambles to each of the four book sections.

It is also necessary to agree on an internationally shared understanding of what an innovative learning environment is. Working against this notion is the primarily culturally specific nature of education at the school level. Every nation-and indeed many provinces and states of those nations - have their own specific educational approaches, nomenclature and agreed standards. It is thus difficult for a project such as this to use an agreed terminology for ILE's.

Fortunately, there are two global organisations which can assist in identifying a shared definition.

Firstly, the Organisation for Economic Co-operation and Development (OECD) had embarked on an innovative learning environments project around the same time as this ILETC project. Thus, the Editors were able to draw from that work to obtain an accepted term for ILE which could be shared by the international participants in the project. Rather than a single statement of what an ILE 'is', the OECD suggested seven principles that serve to shape an ILE. These are the learning environment:

- Recognises the learners as its core participants, encourages their active engagement and develops in them an understanding of their own activity as learners.

- Is founded on the social nature of learning and actively encourages well-organised co-operative learning.

- The learning professionals within the learning environment are highly attuned to the learners' motivations and the key role of emotions in achievement.

- Is acutely sensitive to the individual differences among the learners in it, including their prior knowledge.

- Devises programmes that demand hard work and challenge from all without excessive overload.

- Operates with clarity of expectations and deploys assessment strategies consistent with these expectations; there is strong emphasis on formative feedback to support learning.

- Strongly promotes "horizontal connectedness" across areas of knowledge and subjects as well as to the community and the wider world.

(Source: OECD, 2017, p25)

The OECD study also asks about ILE's:

- Learning focused: How learning focus is the network and how far might it be characterised as innovative? 
- The means of innovation "contagion": The nature of the diffusion within networks and how they spread learning innovation.

- Formal/non-formal balance: How informally networked are formal learning environments; how visible is the non-formal and do the formal and non-formal combine in new "hybrids"?

(Source: OECD, 2017, p81)

Many of these issues are covered neatly in the matrix in as illustrated in Table 1. Indeed, the Chapters in this edited book could be considered to be implementing the transformative Phase 4 of Table 1.

The second global institution, the United Nations Educational, Scientific and Cultural Organisation (UNESCO 2019), developed a Learning Portal to cover many of the same issues as the OECD, although they do tend to cover different socioeconomic demographics, that is to say, developing countries. That said, it is important to consider what innovation means in different countries. In some countries innovation may simply be just having a school to go to, let alone the sophistication of some of the more elite private schools we see in Australia, for example.

The UNESCO Institute for Information Technologies in Education (IITE, 2019) is increasingly tackling some of the more global issues through the lens of innovation. For example, a Ministerial Forum (UNESCO, 2019) picks up on the 'leap' of the use of technology in the developing world, where the virtual is perhaps becoming more viable than the physical in terms of available capital expenditure.

Perhaps the 'elephant in the room' in all of these above observations is how to scale up the concept of an ILE across a national or state school ecosystem.

As noted earlier, the chapters in this book explores some of the issues I have raised, particularly in the Transforming phase of the table above. The contributed research chapters are bookended by chapters from the co-editors-Chap. 1 sets the scene and contextualises the work of LEaRN; Chap. 20 reflects on the contributions in that context and points to the next steps. The other chapters are presented in four sections, each with an introductory essay authored by the editors and myself. This structure will assist the reader to delve into the issues found most pertinent to each reader.

\section{Concluding Remarks: Evidence-Based Design and Translational Research}

This edited book showcases some very innovative research projects-in-progress focussing on transitioning strategies. Within the ILETC project there is emerging a very solid evidence-base of learned material on innovative learning environments. Such a scholarly body of work is difficult to inscribe in the literature, as much learning environment research does not meet sufficient Evidence-Based Design standards or is so multidisciplinary the publication venues can become very opaque. 
Table 1 Phases of Transition in implementing an ICT strategy (Source: Groff, 2013)

\begin{tabular}{|c|c|c|c|c|}
\hline Phase Criteria & Phase 1 Emerging & Phase 2 Applying & $\begin{array}{l}\text { Phase } 3 \\
\text { Integrating }\end{array}$ & \begin{tabular}{|l} 
Phase 4 \\
Transforming
\end{tabular} \\
\hline Vision & $\begin{array}{l}\text { Limited, } \\
\text { pragmatic, } \\
\text { dominated by } \\
\text { interested } \\
\text { individuals }\end{array}$ & $\begin{array}{l}\text { Driven by ICT } \\
\text { specialists }\end{array}$ & $\begin{array}{l}\text { Driven by subject } \\
\text { specialists }\end{array}$ & $\begin{array}{l}\text { Entire learning } \\
\text { community }\end{array}$ \\
\hline $\begin{array}{l}\text { Teaching, } \\
\text { Learning \& } \\
\text { Pedagogy }\end{array}$ & Teacher centred & $\begin{array}{l}\text { Teacher centred, } \\
\text { ICT is a separate } \\
\text { subject }\end{array}$ & $\begin{array}{l}\text { Learner centred, } \\
\text { collaborative }\end{array}$ & $\begin{array}{l}\text { Critical thinking, } \\
\text { preferred learning } \\
\text { styles }\end{array}$ \\
\hline $\begin{array}{l}\text { Development } \\
\text { Plan \& Policies }\end{array}$ & $\begin{array}{l}\text { Accidental, } \\
\text { restrictive, no } \\
\text { planned funding }\end{array}$ & $\begin{array}{l}\text { Limited, } \\
\text { centralised } \\
\text { policies }\end{array}$ & $\begin{array}{l}\text { Individual subject } \\
\text { plans for ICT, } \\
\text { permissive } \\
\text { policies }\end{array}$ & $\begin{array}{l}\text { ICT is integral to } \\
\text { overall school } \\
\text { development plan } \\
\text { (budget, } \\
\text { professional } \\
\text { development, } \\
\text { etc.) } \\
\end{array}$ \\
\hline $\begin{array}{l}\text { Facilities \& } \\
\text { Resources }\end{array}$ & $\begin{array}{l}\text { Limited and } \\
\text { non-current } \\
\text { digital resources, } \\
\text { restricted access }\end{array}$ & $\begin{array}{l}\text { Diverse and } \\
\text { varying in model, } \\
\text { platform; aligned } \\
\text { with specific } \\
\text { content and } \\
\text { pedagogies }\end{array}$ & $\begin{array}{l}\text { Diffused access } \\
\text { to various digital } \\
\text { resources; } \\
\text { supports to } \\
\text { implement these } \\
\text { in various ways }\end{array}$ & $\begin{array}{l}\text { Whole school } \\
\text { learning and } \\
\text { diverse learning } \\
\text { environments; } \\
\text { web-based } \\
\text { learning spaces, } \\
\text { distance } \\
\text { education, student } \\
\text { self-management } \\
\text { software }\end{array}$ \\
\hline $\begin{array}{l}\text { Understanding } \\
\text { of Curriculum }\end{array}$ & $\begin{array}{l}\text { ICT literacy, } \\
\text { responsibility of } \\
\text { individual } \\
\text { teachers }\end{array}$ & $\begin{array}{l}\text { Use of software } \\
\text { and applications } \\
\text { in discrete subject } \\
\text { (isolated) }\end{array}$ & $\begin{array}{l}\text { Integrated, } \\
\text { resource-based } \\
\text { learning, } \\
\text { problem-solving, } \\
\text { project } \\
\text { methodology }\end{array}$ & $\begin{array}{l}\text { Virtual and real } \\
\text { time contexts, } \\
\text { modelling, } \\
\text { integrated } \\
\text { curriculum } \\
\text { delivery via the } \\
\text { web }\end{array}$ \\
\hline $\begin{array}{l}\text { Professional } \\
\text { Development }\end{array}$ & Individual interest & $\begin{array}{l}\text { Training on ICT } \\
\text { applications } \\
\text { unplanned }\end{array}$ & $\begin{array}{l}\text { Subject specific, } \\
\text { evolving }\end{array}$ & $\begin{array}{l}\text { Integrated } \\
\text { learning } \\
\text { community, } \\
\text { innovative, } \\
\text { self-managed, } \\
\text { personal vision } \\
\text { and plan }\end{array}$ \\
\hline
\end{tabular}


Table 1 (continued)

\begin{tabular}{l|l|l|l|l}
\hline Phase Criteria & Phase 1 Emerging & Phase 2 Applying & $\begin{array}{l}\text { Phase 3 } \\
\text { Integrating }\end{array}$ & $\begin{array}{l}\text { Phase 4 } \\
\text { Transforming }\end{array}$ \\
\hline Community & Accidental & $\begin{array}{l}\text { Some parental and } \\
\text { community } \\
\text { involvement }\end{array}$ & $\begin{array}{l}\text { Subject-based } \\
\text { community, } \\
\text { providing } \\
\text { occasional } \\
\text { guidance; global } \\
\text { and local } \\
\text { networked } \\
\text { communities }\end{array}$ & $\begin{array}{l}\text { Broad-based } \\
\text { learning } \\
\text { community } \\
\text { involving } \\
\text { families, business, } \\
\text { industry, } \\
\text { organisations, } \\
\text { universities; } \\
\text { school as a } \\
\text { learning resource } \\
\text { for the } \\
\text { community }\end{array}$ \\
\hline Assessment & $\begin{array}{l}\text { Responsibility of } \\
\text { individual } \\
\text { teacher, didactic, } \\
\text { paper and pencil } \\
\text { based }\end{array}$ & $\begin{array}{l}\text { Teacher centres } \\
\text { and subject } \\
\text { focussed }\end{array}$ & $\begin{array}{l}\text { Learner centred, } \\
\text { subject oriented, } \\
\text { integrated, } \\
\text { multiple media to } \\
\text { demonstrate } \\
\text { alignment }\end{array}$ & $\begin{array}{l}\text { Continuous, } \\
\text { holistic, } \\
\text { open-ended, } \\
\text { project-based, } \\
\text { learning } \\
\text { community } \\
\text { involvement }\end{array}$ \\
\hline
\end{tabular}

This compares to evidence-based medicine which is accepted globally, as a given. This medical concept — known as 'translational medicine' - has been adapted over the past couple of decades within health planning practice (HERD, 2019). But, in educational architecture, a deep evidence-based body of research knowledge on human-environment interaction in school education is still emerging. More importantly, the interaction between research and practice is even less evident in educational architecture. Although this dual-sector is not alone:

'Research is research, and practice is practice, and never the twain shall meet. The gap between these two communities is real and frustrating'. (Norman, 2010)

In response to this dilemma, Norman argues for an integrative approach to research theory and practice through the modality of 'Translational Development'.

Between research and practice a new, third discipline must be inserted, one that can translate between the abstractions of research and the practicalities of practice. We need a discipline of translational development. Medicine, biology, and the health sciences have been the first to recognise the need for this intermediary step through the funding and development of centres for translational science. This intermediate field is needed in all arenas of research. It is of special importance to our community. We need translational developers who can act as the intermediary, translating research findings into the language of practical development and business while also translating the needs of business into issues that researchers can address. Notice that the need for translation goes in both directions: from research to practice and from practice to research (Norman, 2010). 
For school design practitioners, we thus would have:

Translational Research $\Rightarrow$ Translational Development $\Rightarrow$ Translational Engineering $\Rightarrow$ Translational Design

There is currently a cross-disciplinary practice emerging of 'Educational Planning' (A4LE, 2019), which is modelled on the abovementioned health planning sector $^{7}$. This development is reflecting the complex cross-disciplinary processes that underpin the development of effective resilient (complex adaptive) innovative learning environments. This edited book is arguably a compilation of the Educational Planning research efforts of the invited authors, the majority who mix research and practice on a daily basis.

A final word on 'culture'. It seems to this writer that much of the above is bounded by cultures - tribal, territorial, discipline and a host of others which will impact on transitions. Indeed, there are no doubt multiple teacher cultural mindsets (Nahavandi, 2019) which have to be considered when we head — or transition-into the relative unknown in developing innovative learning environments.

May there be many more such scholarly books to accompany this exhaustively researched one.

\section{References}

Abassi, N. (2009). A Pathway to a better personal and social life through learning spaces: The role of school design in adolescents' identity formation. Unpublished Doctoral Dissertation, University of Melbourne.

A4LE. (2019). The Association for Learning Environments.

BSF. (2019). UK Building Schools for the Future capital works programme. https://www.nao.org.uk/ report/the-building-schools-for-the-future-programme-renewing-the-secondary-school-estate/.

Darian-Smith, K., \& Willis, J. (Eds.). (2016). Designing schools: Space, place \& pedagogy. London $\&$ New York: Routledge.

Dewey, J. (1916). Democracy and education: An introduction to the philosophy of education. New York: MacMillan.

Dovey, K., \& Fisher, K. (2014). Designing for adaptation: The school as socio- spatial assemblage. The Journal of Architecture., 19(1), 43-63.

Dussel, I. (2016). Digital classrooms and the new economies of attention: Reflections on the end of schooling as confinement. In: Darian-Smith, K., \& Willis, J. (Eds.), Designing schools: Space, place \& pedagogy. London \& New York: Routledge.

EFL. (2019). Educational facilities clearinghouse. http://www.ncef.org.

Esposito, J., \& Burgat, F. (2003). Modernizing islam: Religion in the public sphere in the middle east and Europe. Rutgers University Press. New Jersey.

Fisher, K. (2005). Proposed planning principles: Linking pedagogy and space. Melbourne: Victorian Department of Education and Early Childhood Development (DEECD). https://www.education. vic.gov.au/documents/school/principals/infrastructure/pedagogyspace.pdf.

Graham, P. (2008). Susan isaacs and the malting house school. Journal of Child Psychotherapy, 34(1), 5-22.

\footnotetext{
${ }^{7}$ In regulating such planners, there is now a move to accreditation: The Accredited Learning
} Environment Planner (ALEP) 
Groff, J. (2013). Technology-rich innovative learning environments. OECD Innovative Learning Environments project. https://www.oecd-ilibrary.org/content/publication/9789264203488-en.

Hattie, J. (2012). Visible learning for teachers. London \& New York: Routledge.

HERD. (2019). Health Environment Research and Design Journal.

IITE. (2019). UNESCO Institute for information technologies in education. Ministerial Forum. Global dialogue on ICT and education innovation-Towards a sustainable development goal for education (SDG4). Proceedings. Moscow.

Imms, W., Mahat, M., Byers, T., \& Murphy, D. (2017). Type and use of innovative learning environments in Australasian schools. In: ILETC Survey No. 1. Melbourne, Australia: University of Melbourne, LeARN. Retrieved from http://www.iletc.com.au/publications/reports.

Knight, T. (1998, August). Struggle for a new public democracy: School community and the State. In: Paper Presented at the British Education Research Association Annual Conference. Belfast: The Queens University.

LEaRN. (2019). The Learning Environments Applied Research Network. https://research.unimelb. edu.au/learnetwork/home and https://research.unimelb.edu.au/learnetwork/home\#projects.

Lloyd-Wright, F. (1902). Hillside home school. Sourced from Frank Lloyd wright trust database. https://www.flwright.org/researchexplore/wrightbuildings/hillsidehomeschool

Logan, C. (2016). Open shut them: open classrooms in Australian Schools, 1967-1983. In K. Darian-Smith \& J. Willis (2017). (Eds)., Designing schools: Space, place \& pedagogy. London \& New York: Routledge.

Marks, J. (2009). A history of Educational Facilities Laboratories (EFL). National Clearing House of Educational Facilities. http://www.ncef.org.

Markus, T. (1993). Buildings \& power: Freedom and control in the origin of modern building types. London \& New York: Routledge.

Nahavandi, A. (2019). https://www.culturalmindset.org/partners and https://catcher.sandiego.edu/ items/soles/Cultural\%20Mindset_Nahavandi.pdf.

Norman, D. (2010). The research practice gap. Association for Computing Machinery (ACM) Journal 'Inspirations', 17(4).

OECD. (2017). The OECD Handbook for Innovative Learning Environments. Paris: Centre for Research and Innovation.

Pike, B. (2005). http://web.education.unimelb.edu.au/curriculumpoliciesproject/Reports/dow nload/Vic-2005-BlueprintforGovernmentSchools2003.pdf.

UNESCO. (2018). Proceedings of the Ministerial Forum: Global dialogue on ICT and education innovation - towards sustainable development goal for education (SDG 4), April. Moscow.

UNESCO. (2019). https://learningportal.iiep.unesco.org/en/issue-briefs/improve-learning/sch ools-and-classrooms/the-psycho-social-school-environment; https://iite.unesco.org/about-une sco-iite/.

Zierer, K. (2015). Educational expertise: the concept of 'mind frames' as an integrative model for professionalisation in teaching. Oxford Review of Education, 41(6), 782-798.

Kenn Fisher (Australia) is recognised as one of the leading learning environment specialists practising locally, nationally and internationally for over three decades. He has practised in Australia, Asia, the Middle East and Europe and as a consultant to the OECD (where he held the post of Head of the Programme on Educational Building in Paris in 1997/8) and UNESCO. He is multiskilled in a range of disciplines having practised in all education sectors as a teacher and academic, a strategic facility and campus planner and as a project, facility and design manager. He has been engaged by more than universities worldwide, over a dozen vocational training and community college clients, a number of State and National Government Ministries of Education, many school organisations and Government and corporate entities. Kenn is an Associate Professor in Learning Environments at The University of Melbourne's School of Design (MSD). 
Open Access This chapter is licensed under the terms of the Creative Commons Attribution 4.0 International License (http://creativecommons.org/licenses/by/4.0/), which permits use, sharing, adaptation, distribution and reproduction in any medium or format, as long as you give appropriate credit to the original author(s) and the source, provide a link to the Creative Commons license and indicate if changes were made.

The images or other third party material in this chapter are included in the chapter's Creative Commons license, unless indicated otherwise in a credit line to the material. If material is not included in the chapter's Creative Commons license and your intended use is not permitted by statutory regulation or exceeds the permitted use, you will need to obtain permission directly from the copyright holder.

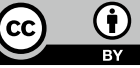

